\title{
Deskripsi Penggunaan Bahasa dalam Iklan Politik pada PILEG 2019 di Kabupaten Sumbawa
}

\section{Hendra Gunawan}

Institut Ilmu Sosial dan Ilmu Budaya Samawa Rea hendg455@gmail.com

\section{Artikel Info}

Tanggal Publikasi

2019-12-30

Kata Kunci

Penggunaan Bahasa

Iklan Politik

\begin{abstract}
Abstrak
Bahasa yang digunakan dalam politik khususnya saat-saat ingin menarik simpati masyarakat memiliki ciri-ciri tertentu. Komunikasi politik tidak bisa dilepaskan dari penggunaan bahasa yang mengarah pada penyampaian pesan, himbauan, harapan, permintaan, dan keinginan untuk mempengaruhi. Dalam menjalankan fungsinya sebagai alat komunikasi dalam bahasa politik, bahasa dikemas dengan menggunakan lambang-lambang atau pesan-pesan yang dapat mewakili ide atau pikiran para penuturnya. Penelitian ini dilakukan sebagai uapaya mengetahui bagaimana bahasa digunakan dalam iklan politik di Kabupaten Sumbawa Besar pada pemilihan umum legislatif 2019 lalu. Metode yang digunakan adalah deskriptif kualitatif. Selanjutnya data dalam penelitian ini berupa data kebahasaan dari spanduk iklan, dan masyarakat sebagai sumber data. Hasil penelitian ini menyatakan bahwa pemakaian bahasa dalam spanduk iklan politik di sumbawa besar berkisar pada level kosa kata, kosa kata yang diperjuangkan, kosa kata yang memarjinalkan orang lain, kosa kata bernuansa kedaerahan, metafora yang berdaya gugah, informatif dan persuasif, relasi makna, dan melalui pronomina. Kesimpulan dari penelitian ini bahwa penggunaan bahasa pada iklan politik pada PILEG 2019 di kabupaten sumbawa bersifat menggugah, informatif dan persuasif. Menggugah maksudnya adalah bahasa yang digunakan sangat mencermati kebutuhan konsumen, memberikan solusi, dan memberikan perhatian lebih kepada masyarakat mengenai PILEG saat itu. Sedangkan informatif bahasa yang digunakan tidak bertele-tele membuat masyarakat mengerti dengan menggunakan bahasa-bahasa politik. Serta persuasif bahasa yang digunakan sifatnya mengajak dan menghimbau untuk memilih para calon saat PILEG.
\end{abstract}

\section{PENDAHULUAN}

Bahasa digunakan untuk membentuk pikiran dan perasaannya, keinginan dan perbuatannya, mempengaruhi dan dipengaruhi. Penggunaan bahasa dalam setiap aktivitas manusia sehari-hari merupakan perwujudan bahasa sebagai alat atau media interaksi antara manusia. Demikian halnya yang terjadi dalam interaksi politik. Interaksi politik merupakan interaksi khusus yang berbeda dengan interaksi sosial pada umumnya. Indonesia tumbuh dan berkembang dari Bahasa Melayu, yang sejak dahulu sudah dipakai sebagai bahasa perantara (linggua franca), bukan saja di Kepulauan Nusantara, melainkan juga hampir di seluruh Asia Tenggara. Zainal dan Amran (2010:5). Menurut Chaer (2009:30) Bahasa adalah alat verbal yang digunakan untuk berkomunikasi. Para pakar linguistik deskriptif biasanya mendefinisikan bahasa sebagai "satu sistem lambang bunyi yang bersifat arbitrer", yang kemudian lazim ditambah dengan yang digunakan oleh sekelompok anggota masyarakat untuk berinteraksi dan mengidentifikasikan diri.

Penjelasan di atas, mendefinisikan bahwa bahasa merupakan komunikasi dalam politik yang memiliki karakteristik khusus, bahasa dijadikan alat untuk pergelaran kuasa-kuasa tertentu, bahkan bahasa mampu menjadi "rezim yang berkuasa". Artinya bahasa mampu mengubah pola pikiran manusia, memerintah pikiran manusia bahkan "merusak"pikiran manusia. Sumarsono dalam 
sosiolinguistik mengatakan bahwa, masalah keanekabahasaan bagi pemerintah memang rumit. Menghapuskan bahasa-bahasa minoritas mendapatkan tantangan. Tetapi "memelihara"dan mengembangkan bahasa-bahasa itu menimbulkan konsekuensi keuangan, dan ini kadang-kadang tidak tertanggungkan oleh negara yang bersangkutan. Masalah lain adalah menghapuskan atau memelihara bahasa-bahasa minoritas selalu saja mengandung resiko terlibatnya politik. Bahasa sering dijadikan alat politik atau alat gerakan politik, baik politik untuk mematikan etnik tertentu ataupun politik untuk mencapai kemerdekaan bangsa.

Memperthatikan lebih seksama, bahwa penggunaan bahasa dalam iklan politik di Sumbawa pada pemilihan legislatif sangat menarik untuk dikaji. Aktivitas ini memperlihatkan bentuk bahasa yang dimanfaatkan sedemikian rupa untuk tujuan yang jelas dan terpusat. Tujuan-tujuan persuasi ditempuh dengan berbagai cara, dari kampanye yang bersifat negatif sampai kampanye yang bersifat positif. Keadaan ini dapat dijumpai pada proses kampanye PILEG yang sudah berlangsung beberapa bulan yang lalu.

Berdasarkan uraian di atas peneliti mencoba mengambil kajian bahasa politik, khususnya dalam Mendeskripsikan Pemakaian Bahasa Dalam Spanduk Iklan Politik di Kabupaten Sumbawa Besar. Sebenarnya ada beberapa Objek yang dapat diteliti untuk mendapatkan data kebahasaan tentang hal tersebut. Namun mengingat keterbatasan waktu dan tenaga, maka objek penelitian ini hanya pada spanduk.

\section{METODE PENELITIAN}

Jenis penelitian ini merupakan penelitian kualitatif dengan menggunakan metode deskriptif kualitatif. Penelitian ini dilaksanakan di Kabupaten Sumbawa. Adapun data dalam penelitian ini adalah bahasa yang terdapat dalam spanduk calon legislative yang tersebar di Kabupaten Sumbawa yang sifatnya menggugah, menarik, informatif, dan persuasif. Sebagai acuan dalam menganalisis beberapa unsur yang menjadi objek penelitian maka langkah yang harus dilakukan, peneliti harus memproleh data dan fakta yang memiliki kaitan erat dengan penelitian berupa data dan sumber data. Sedangkan teknik pengumpulan data yang digunakan dalam penelitian berupa wawancara, observasi, dan dokumentasi. Dalam menganalisis data, peneliti menggunakan langkah-langkah, yaitu reduksi data, transkrips data, dan transkripsi hasil rekaman. Selanjutnya untuk memproleh keabsahan data hasil temuan di lapangan agar makin terpercaya, dalam proses validasi peneliti menggunakan triangulasi untuk menghilangkan perbedaan konstruksi kenyataan yang ada sewaktu pengumpulan data tentang berbagai pandangan.

\section{HASIL DAN PEMBAHASAN}

Berdasarkan penelitian yang dilakukan di lapangan dan ditemukan dari sejumlah calon legislatif yang berasal dari berbagai DAPIL, lintas kalangan, dan pertai politik, baik partai yang berasaskan islam maupun nasionalis. Mulai dari Partai Golongan Karya (GOLKAR) Partai Demokrat (PD), Partai Persatuan Pembangunan (PPP), Partai Keadilan Sejahtera (PKS), Partai Bulan Bintang (PBB), Partai Amanat Nasional (PAN), dan partai lainnya yang ikut serta dalam kancah kompetisi pemilihan umum. Selanjutnya calon yang berasal dari kalangan politisi, pengusaha, incumbent, akademisi, praktisi dan lainnya, kesemuanya dalam mencari simpati pemilih guna memilihnya tidak terlepas dari bagaimana mereka memamfaatkan sejumlah klasifikasi kosa yakni muda, berpengalaman, telah berjuang, cerdas, bersih, perempuan, kompeten, pejuang kepentingan rakyat, dan intelektual. Dari pemilihan kosa yang tersebut di atas, kesemuanya dapat ditemukan penggunaannya dalam bahasa iklan spanduk yang digunakan. Menyederhanakan pembahasan ini, peneliti merangkumnya dalam beberapa klasifikasi kata, antaranya melalui bahasa pencitraan yang dideskripsikan atau dikemas menarik dan berkesan. Yang sesuai dengan struktur kata dalam iklan yang bersifat (1) menggugah, (2) informatif, dan (3) persuasif. Untuk lebih 
memperjelas proses pembahasan pada bagian ini terlebih dahulu peneliti akan menyajikan data data yang menjadi acuan peneliti sesuai yang peneliti temukan di lapangan.

\section{Deskripsi Penggunaan Bahasa Pada Iklan Partai Politik Melalui Kosa Kata yang Diperjuangkan}

Secara ideologis, para calon legislatif yang mengiklankan diri sering sekali kita temui menggunakan kosa kata yang bernuansa perjuangan. Kosa kata utama yang diperjuangkan bertujuan menciptakan citra sebagai pejuang dan pembela kepentingan rakyat. Kosa kata yang diperjuangkan. Diantaranya meliputi, harkat dan martabat petani dan nelayan, kesetaraan perempuan, harkat perempuan, keterwakilan perempuan, dan kejujuran, pendidikan dan kesehatan gratis dan lainnya.

Seperti yang digunakan oleh Rusdi Darmawansyah, salah satu calon DPRD Kabupaten Sumbawa dari partai Kebangkitan Bangsa, Dapil IV, menggunakan bahasa,

"Bersama Petani dan Nelayan, kita gerakkan Perekonomian menuju masyarakat Sejahtera dan Berwibawa"

Sebagai calon yang berasal dari pesisir, dan sekaligus memegang jabatan sebagai sekretaris Perhimpunan Tani dan Nelayan Kabupaten Sumbawa, juga merupakan peternak kuda yang sukses, bagi Rusdi sangat perlu menampilkan sisi keunggulannya. Hal ini dapat ditemukan dalam spanduknya yang selalu menggunakan kata kata yang bernada memperjuangkan nasib dan kesejahteraan petani dan Peternak, dan Nelayan. Meski terkadang tidak banyak yang telah dilakukan, namun dalam upaya ini, seperti yang lumrah kita ketahui, bahwa tidak mungkin mereka mengangkat kekurangan dan keburukannya. Sehingga dengan demikian, salah satu upaya yang tepat guna menarik minat dan simpati masyarakat.

Pada level lain di tingkat DPRD Provinsi NTB, Ilham Mustami, menyebutkan dirinya sebagai salah satu calon yanag memili kepedulian tinggi terhadap nasib rakyat dan penderitaan yang rakyat rasakan selama ini,

"Kita telah lama menjadi budak di daerah sendiri, petani dan nelayan kita berada jauh di bawah kehidupan layak. Tanah dan hasil tambang kita di keruk. Kini saatnya memilih pemimpin yang visioner COBLOS No 8 Paratai Bulan Bintang, Ilham Mustami"

"Sumbawa berada pada poros tengah kepulauan di NTB, PT Newmont Nusa tenggara penyumbang APBN dan APBD aktif, tapi masyarakat Sumbawa masih berada jauh dalam garis kemakmuran.

Mari selamatkan rakyat kita dengan dukung wakil kita yang berani, cerdas dan tau bagaimana menuju samawa yang sabalong samalewa".

Selain itu, tidak ketinggalan juga dalam pemilihan Legislatif yang berlangsung pada bulan April 2019 lalu, Mashun yang diusung dari partai PDIP yang mengikuti persaingan dalam merebutkan kursi dewan di Dapil IV dalam iklan kampanye politiknya lebih cenderung pada upaya rekonstruksi kesejahteraan masyarakat melalui keterwakilannya sebagai salah satu calon yang kerap diusung, dalam iklan politiknya yaitu :

"Sudah saatnya kejayaan masyarakat berada pada tingkat yang diperhitungkan, dengan mebiarkan kesejahteraan nelayan, dan pendidikan terjangkau".

Pada bahasa yang digunakan tersebut, para calon nampak mengeksploitasi tema-tema ekonomi khususnya kesejahteraan, kesetaraan gender, pelayanan masyarakat, dan moralitas sebagai strategi menggaet masa di mata publik. Tema tersebut dengan sengaja di pilih oleh para calon karena tematema tersebut merupakan persoalan nyata yang ada di masyarakat dewasa ini. Dalam persoalan pendidikan, berdasarkan penelitian Organisasi Buruh Internasional (ILO) yang dipublikasikan melalui Tempo Interaktif, sebanyak 4,18 juta anak usia sekolah di Indonesia ternyata putus sekolah dan menjadi pekerja anak. Jika dipersentasikan angka itu setara dengan $19 \%$ anak usia sekolah. Oleh karena itu, 
isu pendidikan yang menjanjikan diharapkan para calon mampu memikat hati pemilih, begitu juga dengan isu ekonomi.

Penggunaan bahasa pada iklan partai politik melalui kosa kata yang diperjuangkan ini merupakan wujud penghargaan simbolik para calon kepada masyarakat untuk meraih kekuasaan. Jumlah anggota masyarakat yang berada pada level ekonomi menengah dan prasejahtera sangat besar. Mereka tentu mengimpikan tingkat kesejahteraan yang lebih baik, layanan pendidikan dan kesehatan yang murah bahkan gratis. Jumlah yang besar dari mereka dijadikan oleh para calon sebagai target perolehan suara dengan mencitrakan diri sebagai pejuang kepentingan mereka, termasuk mencitrakan diri sebagai pejuang kepentingan kaum perempuan. Drummond dalam Jufri $(2008 ; 86)$ menyatakan bahwa ada tiga sumber kekuatan dasar yang dapat dilakukan untuk memperoleh kekuasaan, yakni paksaan, penghargaan material, dan penghargaan simbolik.

\section{Deskripsi penggunaan bahasa pada iklan partai politik Melalui Kosa Kata yang Memarjinalkan Orang Lain}

Untuk mencitrakan diri sebagai calon yang layak dipilih oleh pemilih, Para calon yang berasal dari berbagai kalangan dan partai piolitik, bukan hanya berupaya mencitrakan diri secara positif, tetapi juga berupaya memarjinalkan orang lain. Memberikan kesan positif pada diri sendiri secara implisit dengan mencitrakan calon lain dengan kesan negatif. Dengan memarjinalkan orang lain, para calon berharap memperoleh kesan baik yang bertolak belakang dari calon yang dimarginalkan. Bentuk kosa kata yang memarjinalkan orang lain terlihat dalam bahasa yang digunakan Ikbal Sanggo, Calon DPRD Provinsi Dapil Sumbawa Nomor urut 3 yakni:

"20 tahun daerah kita berada d bawah kuasa Asing dan kekuasaan keluarga. hasil tambang dan bumi lainnya, hanya menjadi penghibur atas derita rakyat, selama kurun waktu itu, siapa yang perlu kita salahkan?? Oleh karena itu, jangan salah pilih lagi, pilih pemimpin yang anti peodalisme, korupsi, kolusi dan Nepotisme"

Selain itu juga terdapat dalam spanduknya,

"Arena politik selama ini diisi dengan bagaimana aktor mencapai tujuan, meskipun menghalalkan beragam cara".

"Kabupaten Sumbawa besar khususnya di kecamatan Buer telah tercoreng nama= baiknya, akibat ulah para anggota DPR asal sumbawa yang terlibat berbagai kasus dan skandal memalukan".

Dalam kutipan di atas, terlihat bahwa berupaya meraih kekuasaan dengan cara memarjinalkan anggota DPR sebelumnya dengan menyebut mereka menghalalkan beragam cara serta terlibat berbagai kasus dan skandal memalukan. Pemarjinalan orang lain ini bertujuan untuk mencitrakan diri sebagai Para calon yang bermoral.

\section{Deskripsi penggunaan bahasa pada iklan partai politik Melalui Kosa Kata Bernuansa Kedaerahan}

Untuk mencitrakan diri sebagai bagian dari komunitas tertentu dan menarik simpati pemilih dari komunitas tersebut, Para calon berupaya mencitrakan diri dengan menggunakan kosa kata bernuansa kedaerahan. Kosa kata bernuansa kedaerahan yang digunakan terdiri atas dua kategori, yakni (1) kosa kata bahasa daerah (2) Bernuansa etnisitas/primordialisme.

Seperti yang digunakan oleh Abdul Majid, salah satu calon legislatif yang berasal dari Kecamatan Buer yang diusung dari partai Demokrat, pada iklan partai politiknya menggunakan bahasa daerah sebagai salah satu upaya dalam menggaet perhatian dan minat masyarakat dalam memilihnya,

"Tubarema sasenap desa para tau, tubarema senyaman ate terok no 10 berpengalaman mensejahterakan masyarakat". 
Dalam arti bahasa Indonesia, kita bersama sama menyejukkan desa kita, kita bersama sama coblos no 10 .

Selain itu juga, Irwansyah dalam iklan politiknya juga menggunakan bahasa daerah sebagai media pengantar kampanyenya, juga menggunakan bahasa daerah Sumbawa.

"Ta tau tepat ade tu pilik, no soda tau ade lebih balong, berema ke masyarakat odek".

Dalam arti bahasa Indonesianya, ini orang yang tepat kita pilioh, tidak ada yang lebih baik, bersama dengan masyarakat kecil.

Penggunaan bahasa daerah seolah-olah menjadi magnet bagi pemilih untuk mencoba menyelam lebih dalam bahwa si calon adalah orang terdekat mereka, si calaon adalah orang yang faham betul bagaimana nasib dan keadaan daerah mereka, hal ini terbukti dengan banyaknya pengakuan masyarakat megenai tingkat penggunaan bahasa daerah yang lebih tepat digunakan dalam menggaet hati dan pilihan mereka seperti misalnya dalam iklan berikut ini yang tersebar di kecamatan Buer,

"Rea let, orong, pani rara ate amen nobau sanyaman kita, pili tau kita, tau do, tapi parak, tau parak sanak kita"

Dalam arti bahasa Indonesianya adalah laut luas, sawah sawah luas sangat disayangkan jika tidak bisa membahagiakan kita, oleh karena itu, pilih orang ya ng berasal dari kita, keluarga dan kerabat kita, sama-sama orang Sumbawa

Selain itu juga dalam iklan laian yang menggunakan bahasa Sumbawa

"Nasa calon nonda sama ke diri ta, tau tengan rara demi tulong sesame kita, no soda ade len, pili bapak ta, ....."

Dalam arti bahasa Indonesianya adalah tidak ada calon yang seperti orang ini, rela menderita demi menolong sesame tidak ada yang lain piliuh orang ini.

"Samawa saleng satotang, saleng beang, saleng beme, saleng pendi saleng salempat, periri desa para kita dengan tupili tau ade berpengalaman"

Dalam arti bahasa Indonesianya adalah Sumbawa saling mengingatkan, saling memberi, saling membimbing, saling mengasihani. Perbaiki tanah kelahiran kita dengan cara memilih orang yang berpengalaman.

Penggunaan pilihan kata ini mengandung nilai ideologis tertentu, yakni para calon berupaya menyentil sentimen etnisitas dan lokal pemilih. Dengan menggunakan kosa kata bernuansa kedaerahan tersebut, Para calon ingin menunjukkan latar belakang kultural atau lokal yang sama dengan pemilih. Dengan demikian, dapat dipahami bahwa Para calon berupaya mendefisikan dirinya melalui pilihan kosa kata dan sekaligus menjadi representasi ideologis untuk menarik dukungan melalui identifikasi etnisitas.

\section{Deskripsi Penggunaan Bahasa Pada Iklan Politik Melalui Bahasa Metafora}

Metafora adalah sebuah makna yang mewakili aspek pengalaman yang lain yang dapat mengandung nilai ideologis (Fairclough; 1995; 136-137). Bentuk-bentuk metafora yang didayagunakan Para calon untuk Deskripsi penggunaan bahasa pada iklan partai politik dirinya dalam wacana iklan kampanye berupa metafora nominatif, metafora predikatif, dan metafora kalimat. Berikut contoh penggunaan metafora dalam wacana iklan kampanye calon anggota legislatif dari Dapil 4, Sri Wahyuni dari partai PKB.

"Perempuan masih diletakkan pada posisi pinggir, kelas dua" 
Pada bahasa iklan partai politik di atas, calon seolah olah mencoba mengajak calon pemilih unuk lebih peka dan memahami posisi mereka terutama kauam perempuan, posisi calon seolah olah akan berposisi sebagai seoarang pahlawan, penolong yang setiap saat akan selalu membela kepentingan dan hajatan pemilih.

Selain itu juga terdapat pada penggalan iklan di bawah ini,

"Strategi yang ia jalankan adalah aspirasi jemput bola".

"Mari jadikan jabatan sebagai masjid, kantor sebagai sajadah, meja kerja sebagai zikir".

Metafora didayagunakan para calon bertujuan untuk membangun suatu keyakinan bahwa para calon yang bersangkutan bercita-cita mulia dalam mengembang tugas sebagai anggota legislatif jika terpilih. Melalui metafora Para calon menunjukkan keinginan untuk membangun relasi intensif dengan konstituen, menciptakan kesan pembela kepentingan kaum perempuan, citra rendah hati, dan kesan amanah.

\section{Deskripsi Penggunaan Bahasa pada Iklan Partai Politik Melalui Relasi Makna}

Relasi makna yang didayagunakan para calon dalam wacana iklan kampanye berupa hiponim. Nilai ideologis yang terkandung dalam hiponim utamanya menunjukkan keyakinan kepada rakyat bahwa calon bersangkutan memiliki pengetahuan yang cukup melalui pengalaman panjang dari berbagai bidang kegiatan. Hal ini dapat ditemukan dalam iklan politik yang digunakan oleh Nurdin Rangga Barani, calon DPRRI partai PPP No 1, Dapil Pulau Sumbawa.

"Dalam kesehariannya, beliau banyak bergaul dengan program program potensial, kemampuannya menyaingi pemimpin pemimpin besar di Indonesia, terbukti menjadikan Pulau Sumbawa Hebat dan bermartabat"

Selain itu juga seorang calon harus memiliki kompetensi tinggi, dan moralitas yang baik. Pada bagian ini hiponim didayagukana oleh para calon karena melalui hiponim mereka bisa mendeskripsikan secara detail atas citra diri yang ingin dibentuk. Melalui deretan prestasi, latar belakang pendidikan, bidang usaha akan memunculkan kesan mumpuni. Berikut terdapat dalam spanduk seorang calon legislatif Provinsi Nomor urut 8 partai PBB.

"Selain Politisi, Ilham Mustami juga menggeluti dunia bisnis sebagai profesional muda dan wiraswasta, berbagai latar usaha yang pernah dan digeluti selama ini; perhotelan, pariwisata, pengembang, perdagangan, dst."

"Saya berjanji untuk tidak melukai nurani masyarakat Kecamatan buer dengan berbagai tindakan tercela, seperti korupsi, khianat terhadap kepercayaan yang diberikan ....dst"

Dalam upaya penggunaan bahasa pada iklan partai politik melalui relasi makna, nampak bahwa para calon berupaya menunjukkan watak dan kredibitas yang dimiliki. Menurut Keraf (2003: 121) persuasi akan berlangsung sesuai harapan, jika penerima informasi telah mengenal pemberi informasi sebagai orang yang berwatak baik.

\section{Deskripsi Penggunaan Bahasa Pada Iklan Partai Politik Melalui Pronomina}

Para calon memanfaatkan tiga bentuk pronomina untuk mencitrakan dirinya, yakni saya, kami, dan kita. Pronomina saya digunakan para calon untuk mengungkapkan citra dirinya dalam bentuk prestasi dan aktivitas positif yang sifatnya dilakukan individual. Pronomina kami digunakan untuk mengacu kepada diri dan sekaligus partai jika skup pemilihannya tingkat daerah atau nasional. Pronomina kita digunakan untuk mengacu kepada diri para calon dan masyarakat calon pemilih. Pronomina ini digunakan dalam aktivitas yang bermakna ajakan untuk melakukan tindakan bersama pada pada datang. 
Pronomina saya dan kami digunakan untuk mereflesikan sikap keakuan. Misalnya yang digunakan Zulkarnain, salah satu calon Legislatif dari partai Golongan karya Dapil IV nomor urut 5 dalam iklan politiknya menggunakan kata kata yang bernuansa metafora yakni :

"Politik bagi saya adalah kerja kemanusia"

"Mari kita mengolah politik untuk kesejahteraan umat"

Pronomina kita digunakan untuk mewujudkan representasi kekuasaan dengan menciptakan makna ajakan, misalnya dalam kalimat Secara tidak langsung, para calon telah menggunakan kekuasaan dan mendominasi pemilih. Dominasi itu terjadi atas legitimasi yang dibuat para calon bahwa politik akan bermuara pada kesejahteraan jika para calon bersangkutan yang mengolahnya.

Jufri $(2008$; 35) mengemukakan bahwa kata ganti (pronomina) merupakan aspek yang dapat dimanipulasi dengan pilihan bahasa untuk menciptakan makna imajinatif. Kata ganti saya dan kami digunakan untuk mengambarkan sikap resmi komunikator semata-mata. Kata ganti kita merupakan representasi dan wujud sikap bersama dalam satu komunitas.

\section{Deskripsi Penggunaan Bahasa Pada Iklan Partai Politik Melalui Kalimat Positif-Negatif}

Bentuk kalimat dapat memiliki muatan ideologis yang mencitrakan para calon dan penggunaan bahasa pada iklan kampanye. Baik kalimat positif maupun kalimat negatif dapat digunakan untuk mengekpresikan ideologi tertentu mengenai kepribadian, kompetensi, ataupun program dari masing masing calon. Berikut contoh kalimat positif dan negatif yang memiliki muatan ideologis Deskripsi penggunaan bahasa pada iklan partai politik bagi setiap calon.

Seperti halnya bahasa iklan politik yang digunakan oleh salah satu calon legislatif Dapil 2, Jasardi Gunawan nomor urut 8 partai PAN yang mengatakan,

"Memperjuangkan layanan kesehatan bagi keluarga miskin.

"Memperjuangkan layanan kesehatan bagikeluarga miskin"

"Memperjuangkan kesejahteraan nelayan"

"Kipranya dalam dunia politik tidak diragukan lagi, dia dikenal luas di tingkat lokal, bahkan di tingkat nasional"

"Kebijakan kurang mengakomodir kepentingan perempuan. Bukan karena laki-laki tidak respek, tetapi mungkin saja karena ketidak tahuan laki-laki terhadap persoalan khas perempuan"

Muatan ideologis pada penggunaan bahasa pada iklan partai politik yang diekspresikan melalui kalimat positif bermakna gamblang, tegas, dan lugas. Ideologi yang diperjuangkan para calon diekspresikan secara langsung dan meyakinkan. Sebaliknya, para calon mengekspresikan penggunaan bahasa pada iklan partai politik diri secara implisit melalui kalimat negatif dengan menggunakan negasi tidak dan bukan. Bahkan pada data 15 menggunakan negasi ganda untuk mengekspresikan secara tidak langsung pada penggunaan bahasa pada iklan partai politik. penggunaan negasi ganda tersebut dilakukan untuk menghindari konfrontasi dengan laki-laki.

Para calon tidak mengambil posisi konfrontatif demi penggunaan bahasa pada iklan partai politik kesantunan dan rasa hormat kepada laki-laki. Hal itu terlihat dari ekspresi ketidak tegasan posisi lakilaki dalam memperjuangkan perempuan dengan menggunakan kata mungkin saja. Strategi ini digunakan para calon untuk tetap menjaga citra di mata pemilih laki-laki dan juga upaya menghindari persoalan gender karena bagaimanapun para calon perempuan juga berharap pemilih laki-laki dapat memilihnya

\section{KESIMPULAN}


Penggunaan bahasa pada iklan politik merupakan salah satu bentuk penggunaan bahasa yang inti dari semuanya bersifat menggugah, informatif dan persuasif. Menggugah maksudnya adalah Bagaimana mencermati kebutuhan konsumen, memberikan solusi, dan memberikan perhatian lebih ke masyarakat agar bisa mengerti tentang pemilihan Legislatif (PILEG) dengan menggunakan bahasabahasa politik. Sedangkan informatif adalah penggunaan bahasa yang komunikatif dan tidak berteletele agar masyarakat mengerti maksud dan tujuan dari para calon dalam pelaksanaan pemilihan Legislatif (PILEG) dengan menggunakan bahasa-bahasa politik. Serta persuasif merupakan penggunaan bahasa oleh para calon yang sifatnya mengajak dan menghimbau khalayak untuk mengikuti dan memilih para calon ketika berlangsungnya pemilihan Legislatif (PILEG).

Para calon yang beriklan berupaya memengaruhi pembaca melalui ide dan gagasan yang ditawarkan. Melalui iklan kampanye, membangun realitas atas dirinya. Realitas itu dibangun melalui penggunaan bahasa pada iklan partai politik, baik secara objektif maupun secara subjektif. Selain itu juga, dalam analisis lebih dalam hal ini merupakan bentuk 'penggalangan' kekuasaan melalui media massa dengan memanfaatkan fitur-fitur linguistik. Melalui iklan, para calon berusaha membujuk masyarakat melalui penggunaan bahasa pada iklan partai politik tokoh.

Hasil penelitian menunjukkan bahwa penggunaan bahasa pada iklan partai politik dilakukan dengan memanfaatkan aspek-aspek formal teks yang biasa peneliti deskripsikan mulai pada level kosa kata dan deskripsi penggunaan bahasa pada iklan partai politik pada level gramatika. Pada level kosa kata, peneliti menemukan penggunaan bahasa yang bersifat menggugah, informative dan persuasive pada : (1) klasifikasi kosa kata, (2) kosa kata yang diperjuangkan, (3) kosa kata yang memarjinalkan orang lain, (4) kosa kata yang bernuansa kedaerahan, (5) metafora (6) relasi makna (7) pronomina, dan (8) kalimat positif-negatif.

\section{Daftar Pustaka}

Arifin, E. Zaenal dan Tasai, S Amran, 2010, Cermat Berbahasa Indonesia. Jakarta: Akademika Pressindo. Arikunto, Suharsimi, 2010, Prosedur Penelitian. Jakarta: Rineka Cipta.

Bakir, R. Suyoto dan Sigit Suryanto. 2006, Kamus Lengkap Bahasa Indonesia. Batam: Karisma Publishing Group.

Budiardjo, Miriam. 2013. Dasar-Dasar Ilmu Politik. Jakarta: Gramedia Pustaka Utama.

Chaer, Abdul. 2009. Psikolinguisti Kajian Teoretik. Jakarta: PT. Rineka Cipta

Moleong, Lexy J. 2013. Metodologi Penelitian Kualitatif Edisi Revisi. Bandung: PT. Remaja Rosdakarya.

Muhtadi, Asep Saeful. 2008. Komunikasi Politik Indonesia (Dinamika Islam Politik Pasca-Orde Baru). Bandung: PT Remaja Rosdakarya.

Mulyana, Deddy. 2013. Komunikasi Politik-Politik Komunikasi. Bandung: Rosda

Prihartini, Niniek. EYD (Ejaan yang Disempurnakan). Mitra Jaya: Surabaya.

Sugiyono. 2009. Metode Penelitian Kuantitatif, Kualitatif dan R E D. Bandung: Alfabeta.

Sumarsono. 2002. Sosiolinguistik. Yogyakarta: Sabda.

Tim Penyusunan Kamus Pusat Bahasa. 2005. Kamus Besar Bahasa Indonesia. Jakarta: Balai Pustaka. (http://aneka-wacana.blogspot.com/2012/05) 